\title{
Tiontú an Chultúir: Affaire Dominici agus Maolra Seoighe
}

\section{Stiofán Ó Cadhla}

\section{Q OpenEdition}

1 Journals

\section{Édition électronique}

URL : http://journals.openedition.org/etudesirlandaises/1941

DOI : 10.4000/etudesirlandaises. 1941

ISSN : 2259-8863

\section{Éditeur}

Presses universitaires de Rennes

\section{Édition imprimée}

Date de publication : 30 décembre 2010

Pagination : $35-50$

ISBN : 978-2-7535-1246-7

ISSN : 0183-973X

\section{Référence électronique}

Stiofán Ó Cadhla, «Tiontú an Chultúir: Affaire Dominici agus Maolra Seoighe », Études irlandaises [En ligne], 35-2 | 2010, mis en ligne le 30 décembre 2012, consulté le 21 avril 2019. URL : http:// journals.openedition.org/etudesirlandaises/1941; DOI : 10.4000/etudesirlandaises. 1941

Ce document a été généré automatiquement le 21 avril 2019.

(c) Presses universitaires de Rennes 


\title{
Tiontú an Chultúir: Affaire Dominici agus Maolra Seoighe
}

\author{
Stiofán Ó Cadhla
}

1 "No doubt about it" a scríobhann Lenaghan, "the Irish have always been very superstitious"." Tá sí ar aon fhocal le Ivimey a scríobh beagnach dhá chéad bliain roimpi ar "superstitious aborigines of that popish country". I gcúrsaí an léinn dhúchais agus an bhéaloidis go háirithe is coitianta an port é go maireann a leithéid seo nó a leithéid siúd de nós nó de nath "fós". Cuireadh suim sa chultúr agus sa dúchas ach is annamh a cuireadh suim go fiosach sa chultúr dúchais ann féin. Is ag iarraidh iad a scarúint óna chéile, nó iad a cheangail faoi choinníollacha faoi leith, a bhíothas le cúpla céad bliain anuas. Is léir go dtuigtear an cultúr dúchais go minic mar chuid de réamhchultúr na hEorpa nó de bhunchultúr an chine. Tá úsáid á dhéanamh de dhulanna éiginnte i léann an dúchais, an tseanchais, an chultúir, an bhéaloidis, na Gaeilge nó an Bhéarla, na Ceiltise, na litríochta, na seandálaíochta, na staire, agus dámha gaolmhara eile chomh maith ní foláir. Ní haon ábhar mór anbhá iad go léir ach rudaí neamhurchóideacha go minic. Tá taithí ag léitheoirí na seánraí seo ar áibhéal, ar rómánsúlacht, ar rámhaille, ar phatuaire "acadúil" nó ar mhíthuiscintí. Tá cuid acu ann le fada mar chuid de ghnáthaimh an léinn nuaaoisigh; an primitíveachas, an éabhlóideachas sóisialta, an réamhstair, an Victeoiriachas agus an Ceilteachas. Tuairimí ab iad a bhí i gcúnamh don rialóir polaitiúil uaireanta agus a raibh a mbrath, ó aimsir Charles Darwin ar a luíod, ar aicmiú an daonnaí agus a chuid eolais. Cruthaíodh sanasán stairiúil eitneolaíoch a bhfuiltear ag triall air ó shin chun tréithe an duine a chur síos.

2 Tá curtha i leith roinnt de na trópanna seo go bhfuil siad fadhbtach nó díobhálach fiú. Tá a bheag nó a mhór den chiníochas, den choilíneachas, den sheobhaineachas, de impiriúlachas, nó díreach den seanaois, ag séideadh fúthu. Áirítear go ndéantar earra deoranta neamhdhaonna, andúchasach de chuid den chultúr de dheasca na fastaíme seo. Fágann cuid de na tuiscintí fiarán ag daoine lena sinsir féin. Tá scoláirí ann gur cuma leo mar gheall ar an bpobal a dhíolann as gnó an taighde. B'fhéidir ná tuigeann siad meáchaint cheart na tuairime, b'fhéidir go dtuigeann ach go mbíonn siad sásta gan aon cheann a thógaint di nó b'fhéidir go dtagann siad go huile is go hiomlán le meon na 
fuarchúise. Is cuma an le cultúr na Gaeilge nó an Bhéarla, nó le cultúr dátheangach hibrideach nó iltheangach a mbítear ag plé is ábhar suime trácht na céille ó dhuine go duine, ó theanga go teanga agus ó chultúr go cultúr. Tá a lán le foghlaim ón tslí a siocann sí ina n-oidhreachtaí, a gcruann sí ina gcultúir, a ndéantar féiniúlachtaí di nó a mbogann sí ina foinse cruthaitheachta agus iontais. Bíonn an tuiscint, agus an mhíthuiscint, ag brath ar nós imeachta an léinn agus an eolais. Is cuid lárnach de phróiseas an chultúir an t-aistriúchán a scaoileann an Ghaeilge, agus a ngabhann de fhíorais, de fhantasaíocht agus den eitneolaíocht léi, isteach ar an stáitse. Tugann an toradh a bhíonn air siar agus aniar sinn trí chomhthéacsaí éagsúla in ealaín an léinn agus an dúchais araon. Caitheann sé solas ar cheist an dhea-chleachtais agus ar thábhacht an aireachais i ndéanamh an léimh $\mathrm{i}$ léann an chultúir agus an dúchais. Sa pháipéar seo tá sé i gceist agam cás Mhaolra Seoighe a phlé, cás a bhí chomh cáiliúil sin lá den saol gur scríobh Seoigheach eile faoi agus é na mílte míle ó Chontae na Gaillimhe ${ }^{3}$. An cheist atá orm ach conas mar a chuaigh an taistriúchán i bhfeidhm ar an gcás cúirte. Déanaim ceangail faoi leith chomh maith idir an cás sin agus cause célèbre eile, an affaire Dominici.

\section{Léann an aistriúcháin agus dearcadh an eitnagrafaí}

3 Is fiú dul siar i dtosach ar chuid de na haighnis i léann an aistriúcháin. Is é an míniú bunúsach a thugtar ar an dtiontú ach téacs bunúil a scríobh as an nua i dteanga eile. Is acmhainn dó a bheith cruthaitheach, díobhálach, nuálaíoch nó brúidiúil ${ }^{4}$. Braitheann sé go minic ar straitéis an tiontaitheora nó ar aidhm an aistriúcháin. Tá tábhacht ag gabháil le ról an tiontaitheora mar mhínitheoir, deir Venuti, "translation is a process by which a chain of signifiers that constitutes the source-language text is replaced by a chain of signifiers in the target language which the translator provides on the strength of an interpretation" ${ }^{5 "}$. Luíonn Al Shabab ar thábhacht an léimh sa scéal chomh maith, "translation is the interpretation of linguistic/verbal text in a language different from its own". Tá a lán ceisteanna curtha mar gheall ar chúrsaí aistriúcháin. Canathaobh go bhfuil gá leis? An amhlaidh go bhfuil fabht ar an chéad leagan? Cé a dhéanann é agus cén chúis atá leis? Conas a roghnaítear an téacs? Cad iad na critéir a bhain leis an rogha? Cén comhthéacs ina ndéantar é? Cá bhfios do chultúr na sprioctheangan go bhfuil a cheart tugtha don téacs? Déanfaidh mé iarracht meabhair a chaitheamh leis na ceisteanna seo $\mathrm{i}$ gomhthéacs an aistriúcháin agus an chultúir dhúchais trí chéile ${ }^{7}$. Ní díreach go mbíonn macasamhail á sholáthar i dteanga amháin d'fhocal i dteanga eile. Is casta ná sin é. Bíonn tuiscint á thiontú ó ghréasán siombal agus solaoidí go chéile. Ceileann neafais an tslaitín draíochta a bhíonn ag an dtiontaitheoir cuid de na beartais:

Translation has to do with authority and legitimacy and, ultimately, with power, which is precisely why it has been and continues to be the subject of so many acrimonious debates. Translation is not just a "window opened on another world", or some such platitude. Rather, translation is a channel opened, often not without a certain reluctance, through which foreign influences can penetrate the native culture, challenge it, and even contribute to subverting it ${ }^{8}$.

Áirítear gur mó ná comharthaí teangeolaíocha a cuirtear anonn. Is toradh é uaireanta ar chuimilt fhada eitneagrafaíochúil a bhíonn ag cultúir lena chéile. Tagann léamh an chultúir lárnach, déantar cuid de chóras an mhíniúcháin de: 
The entire system by which one culture comes to interpret, to represent, and finally to dominate another. It includes, in other words, the discourse of colonialism as produced in such forms as imaginative literature, journalism, travel writing, ethnographic description, historiography, political speeches, administrative documents, and statutes of law 9 .

5 Téann cultúir ar imirce, cuirtear thar eolas iad agus nára maith acu agus déanann pobail eile a gcuid féin díobh ${ }^{10}$.

6 I bhfolach taobh thiar d'aistriúcháin líofa a bhíodh tiontaitheoirí go dtí le déanaí. Aistriúcháin ab ea iad ná raibh aon lorg orthu a sceithfeadh gur aistriúcháin a chuige iad. Níor dhóigh leat orthu gur cuireadh isteach ná amach ar an dtéacs nó go raibh aon rud tar éis tarlú. Déanann réimis pholaitiúla a mbíonn suim acu i bpobail dheoranta modh mínithe den aistriúchán ó am go ham nuair a oireann. Tá sé ar chumas an aistriúcháin an t-athrach mianaigh nó an deorantacht sa chultúr eile a thabhairt chun tíreachais. Is é an toradh a bhíonn ar an aistriúchán líofa ach go mbraitheann an léitheoir sa bhaile i gcónaí. Ní chuirtear thar lear in aon chor é ach aithníonn "his or her own culture in a cultural other, enacting an imperialism that extends the dominion of transparency with other ideological discourses over a different culture ${ }^{11}$ ". Glactar leis gur gá dul amach ar dháileadh agus ar struchtúir na cumhachta sa chultúr trí chéile chun aistriúchán a mheas ${ }^{12}$. Ní mór aghaidh a thabhairt ar chruthú, ar leathadh agus ar imirthí an eolais agus ar an míniú a tugtar air sa chultúr eile. Tugann an tiontú chomh fada le croílár phróiseas an chultúir tú. Is deacair don duine é a sheachaint fiú amháin taobh istigh de chultúr agus de theanga aonair. Is furasta a thuiscint conas gur iompaigh sé amach ina mheafar don eitneagrafaíocht féin. Is é an t-eitneagrafaí an tiontaitheoir sa chás seo agus é nó í ag iarraidh dearcadh nó déanamh an chultúir eile a chur in iúl i gcomhthéacs nua nó $\mathrm{i}$ dteanga nua go minic. In Éirinn ní hann dúinn dá éagmais go minic. Ceistítear cruthú an eolais ó aimsir an iarstruchtúrachais ar a luíod, déantar amach nach gan chúinse a cuirtear ann é nó go mbíonn an claonadh fite fuaite ann ó thosach. Ní bhíonn sé neodrach anaithnid i gcónaí, is féidir daoine faoi leith a aithint a dheachtann é bunaithe ar chlár réime a bhíonn pearsanta, proifisiúnta, eacnamúil nó polaitiúil go minic.

7 Is cuid de chúlra ealaín an léinn le fada an seanchas, an teanga, nósanna agus staid an duine a tharraingt isteach i bpróisis straitéiseacha aitheantais, neamhaitheantais, coimhthíochais agus tíreachais ${ }^{13}$. Tá tosach slí le tamall maith de bhlianta ag dioscúrsaí institiúdiúla, eolaíochtúla, impiriúla ar sheanchas sa chaoi is go gcoinníonn siad smacht ar mhínithe faoi leith ${ }^{14}$. Iompaíonn na dioscúrsaí tosaigh seo amach ina "normáltacht". Brúnn siad gaol ar acmhainní siombalacha an chultúir sprioctha. Déantar cuid dhathannach neafaiseach de féin de uaireanta agus cromann sé ar é a mhíniú don saol mór agus é a chur i láthair ar shlí a oireann dá léamha féin. Bíonn eolas an duine eile ar snámh i ríocht siceolaíochta nó, ar a laghad, ar imeall an réalaíochais a bhíonn faoi réim is faoi mheas ag tráth faoi leith. Tuigtear go mbíonn an seaneolas, an teolas bunaidh nó bunúil, balbh feasta: fo-oibiachtúil, míréalta nó mífholláin fiú. Tugtar le tuiscint gur leagan bocht meata d'fhoirm uilíoch aonair amháin eolais é. Déantar tiontaitheoir den chóilíneoir, den rialóir (den iriseoir, den bhreitheamh, den Ghárda, den scoláire, den léiritheoir), gothaí an bholgchainteora aige, ag cur na bhfocal i mbéal an dúchasaigh. Bíonn sé de bheith sa dúchasach titim ina phleist bhalbh mharbh i éagmais an tiontaitheora. Is ceart a mheabhrú gur as Béarla, ag tiontú go Béarla nó ag brath ar 
aistriúcháin go Béarla atá an léann le fada. Tá gothadh uile an lingua franca ag an mBéarla inniu.

8 Is iad na gnéithe neamhtheangúla den aistriúchán a spreagann an léamh ildhisiplíneach. Admhaítear ó am go ham mar shampla nach foláir don tiontaitheoir eolas eitneagrafaíochtúil a bheith aige ${ }^{15}$. Ní foláir don eitneagrafaí eolas ar an dtiontú a bheith aige ach oiread. Bíonn sé nó sí i riocht bleachtaire agus aghaidh á thabhairt acu ar "the baffling chaos of cultural artefacts, to discover order in the foreign, and to transfer implicit meanings from one discourse to another ${ }^{16 "}$. Sna dioscúrsaí léannta agus pobaldha is rómhinic gur coincheapa claonta, "easpa tuisceana" agus "anriail" an dúchasaigh mar shampla, a bhíonn mar thoradh ar an dtiontú. Maítear gur féidir lorg an eadarnaí a thabhairt faoi ndeara i bpátrúin reitrice, i solaoidí agus i struchtúir thuisceana an údaráis. Moltar iarracht a dhéanamh gach tabhairt amach a chur i gcomhthéacs dioscúrsach stairiúil faoi leith. Is minic cultúir ina gcéilí comhraic ar stáitsí móra na staire agus bréag á chur ar a chéile acu chun dealramh na fírinne a chur ar a insint féin. Ní mór iarracht a dhéanamh miotas a aithint ó mhítheist. Ní fíor gur teanga mhionlaigh nó teanga nár labhair oiread sin daoine í an Ghaeilge sa naoú céad déag mar shampla. Chaithfí mórtheanga a thabhairt uirthi ach í a bheith gan stádas, gan chumhacht, gan ghradam. B'é an Béarla teanga na cumhachta, an cheannais agus na féiniúlachta cóilíní. Sa chomhthéacs áirithe seo bhí scoláirí dúchasacha ag teacht i dtír ar an éileamh a bhí ann don tiontú ó Ghaeilge. Is ag cur le húdarás an Bhéarla a bhíodar sa mhéid sin ar deireadh agus ag imeallú na Gaeilge ${ }^{17}$. In Éirinn na haimsire sin ní raibh a mhalairt de thuarastal le fáil ag an scoláire go minic.

9 Ní hamháin gur meafar an tiontú don phróiseas cultúrtha sa naoú céad déag ach is cuid den phróiseas é. Is cuid de chorraíocht dhioscúrsach i bpolaitíocht na féiniúlachta é ${ }^{18}$. Is tiontú ó Ghaeilge go Béarla a rinneadh don chuid is mó agus is ag dul le tiomáint agus le sceitheadh an chultúir trí chéile a bhí sé sin, "Irish is translated into English, whether it is by surveyors, writers or antiquarians, because the Empire whether British or AngloAmerican, is leading the way ${ }^{19}$ ". Nochtann téacs tosca an chaidrimh dhaonna, "the relative submissiveness or superiority of the translator and the authority of the receptor culture vis-à-vis the source ${ }^{20 "}$. Is toradh an tiontú i gcásanna áirithe ar éagothromaíocht shóisialta, pholaitiúil nó chultúrtha. Bíonn feidhm chumhachta leis, "the colonial Other is translated into terms of the imperial Self, with the net result of alienation for the colonized and a fiction of understanding for the colonizer ${ }^{21}$ ". Tá sé ráite cheana go dtógann léann an chultúir tamall de thrópanna seanbhunaithe seanchaite éiginnte ón ársaíocht nó ón tseandálaíocht. Is é an toradh is feiceálaí a bhí ar a leithéid ach an timeartas aimsire a chuir an cultúr dúchais siar ar fad ó leac an dorais go dtí leac na Clochaoise. Tugann McNiven agus Russell antiquation air, "the notion that Australian Aboriginal people, along with some other contemporary Indigenous peoples, represented (and perhaps in some cases continue to represent) "living fossils ${ }^{22}$ ". I gcúrsaí an aistriúcháin samhlaítear teanga bhunúil go minic mar iarmhairt chorr: oidhreacht d'iairiglifí atá neamhchoitianta amach is amach. Fágtar teanga atá beo nua-aoiseach comhaimseartha faoi fhocleolaí nó faoi sheandálaí a scaoilfidh na nodanna doléire doléite don léitheoir dall. Go deimhin ní haon ionadh dá mbeadh trua ag an léitheoir don saineolaí bocht ag iarraidh brí a bhaint as míreanna rúndiamhra na réamhstaire. Cad a dhéantar leis an gcultúr nó leis an dteanga sin, conas a mhínítear iad agus cén chúis?

Le linn don Suirbhé Ordanáis a bheith ag mapú na hÉireann sa naoú céad déag shíl roinnt daoine gurb é an suirbhéir nua-aoiseach a bhí i ndiaidh deiridh. B'ait leo an tóir a bhí aige 
ar shean-inscríbhinní agus i gcás amháin bhí ainm an naoimh a bhí uaidh ar eolas go fairsing ach amháin nár chuir sé an cheist. B’fhéidir nár thuig sé go mbeadh aon teacht aige go brách i measc na ndaoine timpeall air ar eolas a bhí ársa dar leis féin. Chuirfeadh a leithéid ort a chuimhneamh gurbh iad na daoine a bhí nua-aoiseach fad is a chuir meon aigne an ársaitheora agus compás an tsuirbhéara an tír faoi dhraíocht. Thóg Cronin ceann de thróp seo na seandálaíochta, "the translator like the archaeologist rescues records from oblivion. The 'site' of translation is the patient unearthing of the language and literature of ancient civilizations ${ }^{23}$ ". Ba chuid den phróiseas, nó toradh ar an bpróiseas, sibhialtacht ársa a dhéanamh de chultúr nua-aoiseach. Ní clabhsúr an tiontú i gcónaí, is tús é babhtaí. Ligeann sé do dhaoine idir theangacha agus chultúir a ionramháil a thuilleadh i saol eile an aistriúcháin. Is í an teanga chumhachtach a éiríonn ar barr de ghnáth agus scóp aici cur léithi féin. Déantar fotheanga nó foinse den teanga bhunúil i ndioscúrsa na hoidhreachta náisiúnta agus an dúchais. Tá iarracht den chóilíneachas ag gabháil leis an dtróp seo. Deir Cronin, "by positing translation as an act of retrieval, the implication is that the other language and culture is lost to the reader in its original form. They are lost both in the sense of coming from a very remote time and being condemned to the oblivion of obsolescence ${ }^{24 "}$. Bíonn an chailliúint mar a bheadh cros os ceann an chine, bíonn an tarrtháil tráthúil laochúil i gcónaí. Maíonn Wolfe nach ann don chailliúint ach amháin i dtéacs an eitneagrafaí, ar theagmháil leis an duine ní hann dó a thuilleadh. Cinneann an loighic i struchtúr an eolais nach suim a cuireadh sa phobal ar mhaithe leo féin go minic ach ar mhaithe leis an solas a chaithfidís ar an seanreacht, ar an gclochaois nó ar na meánaoiseanna. Nuair a chuaigh Flower ar na Blascaodaí d'fhág sé slán "not only to Ireland, but to England and Europe and all the tangled world of to-day ${ }^{25 "}$.

11 Tráchtann Venuti ar an lámh láidir san aistriúchán. Stracann an tiontaitheoir luachanna, creidiúintí agus friotal ón dteanga bhunúil agus cuireann luachanna, creidiúintí agus friotal na teanga sprioctha ina n-áit. Cuireann sé nó sí téacs soléite intuigthe in áit an téacsa deoranta:

[...] translation is the forcible replacement of the linguistic and cultural difference of the foreign text with a text that will be intelligible to the target-language reader... whatever difference the translation conveys is now imprinted by the target-language culture, assimilated to its positions of intelligibility, its canons and taboos, its codes and ideologies ${ }^{26}$.

Dob fhéidir le rialóir cead cainte agus cead mínithe a chur chuige féin, "translation serves an imperialist appropriation of foreign cultures for domestic agendas, cultural, economic, political ${ }^{27}$. Tugann sé le fios, nó ligeann sé air, gur féidir gach pobal, gach teanga, gach cultúr a thuiscint. Cuireann sé air féin gur tarrtháil a bhíonn ann:

[It] effaces its own mark of appropriation by transforming it into the response to a putative appeal on the part of the colonized land and people. This appeal may take the form of chaos that calls for restoration of order, of absence that calls for affirming presence, of natural abundance that awaits the creative hand of technology. Colonialist discourse... appropriates territory, while it also appropriates the means by which such acts of appropriation are to be understood $^{28}$. 
13 Is cleachtas liom-leat é uaireanta, tógann sé le linn do leagan, scríobhann sé an fhad is a scriosann sé, molann sé le linn do a bheith ag cáineadh, séanann sé sa tabhairt faoi ndeara féin.

\section{An tiontú mar ábhar tuisceana}

14 Miotas a thugann Barthes ar thrédhearcacht na hurlabhra. Daoradh Gaston Dominici, feirmeoir sa La Grand Terre i bProváns sa bhliain 1954. Cuireadh ina leith gur dhúnmharaigh sé triúr turasóirí ón mBreatain. Gearradh téarma príosúnachta air ar deireadh agus fágadh a cheann ar a cholann ach ba dhóbair dó. Scaoil charles de Gaulle amach ar na grásta é agus fuair sé bás sa bhliain 1965. Ocht mbliana agus ceithre scór a bhí aige. Seachtó a ceathair bliana roimhe sin, i mí na Nollag 1882, crochadh Maolra Seoighe i gcathair na Gaillimhe. Cuireadh ina leith gur mharaigh sé cúigear as aon líon tí amháin, gaolta leis féin. Ó Dhúiche Sheoigheach ar theorainn iarthuaisceart chontae na Gaillimhe ab ea é. Tugtar affaire Dominici ar chás na Fraince. Glactar leis anois ná raibh ceachtar acu ciontach. Scríobh Barthes mar gheall ar affaire Dominici, "literature has just condemned a man to the guillotine ${ }^{29 "}$. An fiú fiafraí cad a chroch an Seoigheach? An le reachta agus le rialacha amháin a bhaineann an dlí nó an coincheap saor ó éiginnteacht, ó thuairimíocht nó ó chlaontaí an chultúir agus an léinn é? Bíonn lucht léinn agus lucht dlí in ainm is a bheith faoi smacht ag modhanna agus ag teoiricí a thugann cothrom na Féinne do gach aon taobh. Ní mar sin díreach don iriseoir, don scríbhneoir, don úrscéalaí, don drámadóir, don bhfile ná don tuairisceoir ach cad mar gheall ar an eitneagrafaí agus ar an mbéaloideasóir? Is cuid de ealaín an tráchtaire an míniú, an múnlú, an tiontú agus an láimhseáil a dhéanann sé nó sí ar thuairim an phobail. Níl an dlí gan a rian féin de chultúr an lae, cultúr an uachtair go minic. Áitíonn Barthes go mbíonn gach alt agus gach ponc den dlí fite le chéile ag snátha éagsúla ón dteanga amach. Chun teacht ar réiteach, ar chinneadh, ar bhreith nó ar thuairim fiú, ní mór léamh fairsing a dhéanamh ar chomhthéacs an cháis. Ní mór dul i muinín an chultúir.

Téann ceist Barthes go dtí croí an léinn agus cabhraíonn linn tábhacht an léimh chultúrtha a thuiscint. Ar a shon is go bhfuil gach dealramh ar an scéal go bhfuil an léann tar éis an cheist a sheachaint is léir go bhfuil ábhar mór suime inti. Iarann sé orainn na coincheapa móra a aithint sna dioscúrsaí éagsúla a mhíníonn aon ré stairiúil, sna "cultural assumptions and language of taste ${ }^{30 "}$. Fiafraíonn Brett conas gur tháinig sé de bheart i gcás stair a dhéanamh de choincheapa ealaíonta? Conas a meascadh ealaíontóireacht agus scoláireacht mar a rinneadh sa phictúrthacht, ón Iodáilis pittoresco, agus san alltacht a dtugtar an sublime air ${ }^{31}$ ? Bhí oilteacht áirithe tagtha do léann na tíre agus an duine sa naoú céad déag cheana féin, "a smorgasbord of the embryonic genre of evolutionary science blended language agus race to create a colonialist and commoditized English image of Ireland ${ }^{32}$ ". Bhí taithí ag léitheoirí ar seánraí na hársaíochta agus na turasóireachta a thrácht ar Dhúiche na Loch i Sasana, ar Gharbhchríocha na hAlban, ar an mBreatain Bheag nó ar iarthar na hÉireann. Bhí ainm Thomas Crofton Croker in airde, bhí cáil ar Walter Scott, ar James Brewer, ar T. K. Cromwell nó ar G. N. Wright. Dlíodóir ab ea John Carr a chuaigh sé le scríbhneoireacht taistil ${ }^{33}$. Eolaí talmhaíochta agus polaiteoir ab ea J. C. Curwen ${ }^{34}$. Mac dlíodóra ab ea Henry D. Inglish a scríobh ar na bruíonta: "I do not know any means, by which so much insight is to be obtained into the character of the Irish peasantry, and into the condition of the country, and state of things among the lower classes of society, as by listening to these prosecutions for fair murders ${ }^{35}$ ". Bhí 
William Makepeace Thackeray, údar The Luck of Barry Lindon, ina iriseoir óg nuair a tháinig sé go hÉireann i dtosach ${ }^{36}$. D'fhoilsigh Thomas Carlyle Reminiscences sa bhliain 1882, an bhliain a crochadh Maolra Seoighe ${ }^{37}$. Shíl Carlyle gur mithid muintir na hÉireann a chur ar bhóthar a leasa, é sin nó iad a seilg den saol $\operatorname{ar~fad~}^{38}$.

Bhí blúirí beaga den eolas eitneagrafaíochtúil, agus é sin á thuiscint mar thraidisiún réamh-nua-aoiseach, ag cur leis an íomhá dheoranta de chultúr na tíre. Scríobh $\mathrm{H}$. V. Morton, údar In Search of Ireland (1930), mar gheall ar chailín a casadh air i gConamara: "here, within twenty four hours of London, was a primitive woman ${ }^{39}$." Deir ó Ciosáin, "assumptions about literacy and orality are... not untypical of the primitivism through which western areas of Ireland were perceived... E. M. Forster, in an introduction to the Maurice O'Sullivan's Twenty Years A-growing, refers to the Blasket islanders as living in a 'neolithic' civilisation"0". Glacadh lena leithéid mar chuntas léannta fiú. Níl aon rud le foghlaim as ach an méid a fhoghlaímid mar gheall ar an té a scríobh. I gcúrsaí seandálaíochta nó litríochta níl aon díobháil mhór déanta, mar a mhaígh Barthes, ach nuair a nochtann tuairim mar seo i réimse an dlí is scéal eile ar fad é ${ }^{41}$. Deir McNiven agus Russell gur rianta den éabhlóideachas sóisialta atá iontu agus go maireann siad i gcónaí inár measc ${ }^{42}$. Ó foilsíodh On the Origin of the Species by Means of Natural Selection sa bhliain 1859, tá éileamh ar leagan áirithe de chultúir na ndaoine. Bhí tuairimí Thomas Huxley, údar Evidence of Man's Place in Nature (1863) agus John Lubbock, údar Pre-Historic Times: As Illustrated by Ancient Remains, and the Manners and Customs of Modern Savages (1865) á scaipeadh ${ }^{43}$. Chuir Huxley agus Lubbock seanuirlis ón Chlochaois i gcomparáid le huirlisí nua-aoiseacha na tíre ${ }^{44}$. Leath tuairimí Edward B. Tylor, údar Researches in the Early History of Mankind (1865) agus Primitive Culture (1871); agus tuairimí Lewis Henry Morgan, údar Ancient Society (1877). Bhí margadh ann d'fhoilseacháin ar chultúr an duine sa naoú céad déag. Scríobh Andrew Lang mar gheall ar obair Tylor go raibh sé "so attractive, so pellucid, that any intelligent child could read it and become a folk-lorist unawares ${ }^{45}$ ". Bhí William Wilde ag caint ar "popular belief and folks-lore" sa bhliain 1849 agus gan ach trí bliana ann ó chun William Thoms an Béarla folk-lore ${ }^{46}$. Tá raidhse samplaí againn ón bhfichiú haois fiú. Sa bhliain 1957 thug Estyn Evans iarsmaí fiannacha ar chuid d'uirlisí na tíre, agus an tuiscint chéanna ar sheanchas na ndaoine aige, "Ireland is one of the last homes of the oral traditions of prehistoric and medieval Europe ${ }^{47}$ ". D'fhág intinn Tylor séala buan ar léann nua-aoiseach an chultúir. Naoi mbliana éigin i ndiaidh chrochadh Mhaolra Seoighe a tháinig C. R. Browne agus A. C. Haddon go Maigh Eo chun suirbhé eitneagrafaíoch a dhéanamh don saotharlann antraipeolaíochtúil i gColáiste na Tríonóide.

Chuir an t-eolas iontas, alltacht agus masmas ar phobal léitheoireachta na gcathracha, na mbailte móra agus na hEorpa. Bhí tóir ar litríocht na hársaíochta, ar nósanna agus ar phiseoga na muintire. Bhí eolas áirithe ar léann an bhéaloidis agus na hantraipeolaíochta ag sceitheadh amach go dioscúrsaí na litríochta, na polaitíochta agus na hiriseoireachta. Chuir sé séala na heolaíochta ar chlaonta creidimh, ciníocha, aicme nó coilíneachta. Ní eolaíocht a bhí ann go minic ach móitíf de chuid ealaín an íomháineachais. Deir ó Conchubhair "Bhí téamaí na cros-síolrachta, bua na hoiriúnachta, teip na gciníocha laga, agus sainmhíniú idir speicis (teangacha) agus típeanna (canúintí) lárnach do theoiric Darwin ${ }^{48 "}$. Tógadh ceann go minic de thithe nó d'iompar na ndaoine. Rinne roinnt tráchtairí amach gur fabht sa chine, comhartha ar mheath an duine a raibh éasc ó dhúchas ann b'fhéidir, a bhí sa ainriocht shóisialta ábhartha seo ach bhí a thuilleadh ag cásamh gur réimeas cam faoi ndeara é ${ }^{49}$. Scríobh comhfhreagraí amháin mar gheall ar an dtigh inar dúnmharaíodh an cúigear i Mám Trasna, "it would be impossible to imagine 
anything meaner, or more horrible as the habitation of human beings ${ }^{50 "}$. Chuir gnéithe den chultúr dúchais leis an bpictiúr. Thug an Daily Express cuntas ar "traditional wake":

During the evening a considerable number of the women living for miles around, with a number of men, gathered on the mountain close to the Joyces' house and set up a low wailing keen for the dead. Dressed, as the females were in short red petticoats (and shawls) and sitting close together on the short grass of the upland, many of them smoking clay pipes, the sight presented a curious and novel one ${ }^{51}$. neamhchoitiantacht ag gabháil leis na daoine. Tugtar le fios go bhfuil na dúchasaigh traidisiúnta murab ionann agus lucht a mbreithnithe. Baineann siad le ré eile ar fad. Míníonn údar an leabhair féin gur caoineadh an chlann "in the traditional Irish fashion ${ }^{52}$ ". Luann sé féin superstitions go minic agus é ag titim le seanthróp na n-ársaitheoirí, na niriseoirí agus na cinsealachta sa naoú céad déag.

Maidir le cás Mhaolra Seoighe tugann Waldron le fios nach raibh aon Ghaeilge ag an gcuid is mó de na breithimh, de na dlíodóirí ná den chonstáblacht. Fágann sé sin gur ag tiontú ó Ghaeilge go Béarla agus ó Bhéarla go Gaeilge a bhíothas. Bhí seasamh agus dánacht ag an mBéarla i dtigh na cúirte, rud a cuireadh i bhfeidhm go héifeachtach. Deirtear go raibh dlíodóir na Coróineach ag cur na súl trí na cúisithe sna heatraimh le linn an aistriúcháin, "he used periods of translation to eyeball his victims towards panic ${ }^{53}$ ". Bogadh an triail go dtí cathair Bhaile Átha Cliath sa chaoi is go n-éisteodh giúiré speisialta an cás. Aontachtóirí nó dílseoirí don chuid is mó a bhí rompu ann, ba bheag an lé a bhí acu le "uncouth, Gaelic-speaking, poorly-dressed, peasants ${ }^{54 "}$. Níor thuig formhór na bpríosúnach aon Bhéarla, bhí beirt a raibh cúpla focal Béarla acu ach deirtear go raibh béarlagar na Cúirte agus tuin na ndlíodóirí ag dul os ceann meabhrach orthu siúd. Tiarna Talún, George Orme Malley, a bhí ag feidhmiú thar ceann na bpríosúnach. Nuair a cuireadh ar a shúile don bhreitheamh ná raibh aon Bhéarla ag na príosúnaigh, cheap sé póilín ina fhear teanga. Ní hamháin go raibh seasamh agus dánacht ag an mBéarla ach bhí smacht agus cead a chinn geall leis aige. Bhí na cúisithe ar taispeáint don saol mór sa phríomhchathair mar shamplaí de bhunchruth an duine. Ba é an dá mhar a chéile dóibh é dá molfaí iad nó dá gcáinfí iad. Bhí an tsamhlaíocht liteartha léannta ar ligean. Thrácht an Freeman's Journal ar "the conventional type of western peasant ${ }^{55}$ ". Mhol an breitheamh "character, education and intelligence" an ghiúiré agus an t-olc a cuireadh ar an domhan sibhialta ${ }^{56}$. Luaigh an Aturnae Ginearálta an sceimhleadh a cuireadh ar "the Ireland we all knew" agus luaigh dlíodóir na Coróineach gur tháinig "loyal and brave men, as ever maintained the honour of British Arms" ón dúiche chéanna agus gur dóigh leis go dtiocfadh a thuilleadh fós as. Thug sé moladh do na brathadóirí:

[...] three honest peasants from the district... it is some symptom of recovery and of regaining the ancient way, it is some symptom of the natural indignation rising up in the minds of our countrymen against crime and outrage, the three honest peasants who had lived their simple and homely lives in faith and honesty in that part of the countryside are now communicating with the police ${ }^{57}$.

20

Deir Barthes, "the law depicts you as you should be and not as you are ${ }^{58}$ ". Íomhá de thuathánaigh macánta, simplí, piseogach atá ann, tuathánaigh mar ba mhaith leis an 
impireacht iad a bheith. Crochadh Pádraig Shéamais ó Cathasaigh nó "Pat Casey" mar a tugadh sa chúirt air. Dúirt sé leis an mbreitheamh nár thuig sé cad a bhí á rá agus, nuair a aistríodh an chaint dó, chuaigh sé ar an gcúis a shéanadh láithreach ach ní raibh aon mhaith dó ann ${ }^{59}$.

21 An chéad duine eile a glaodh ach Maolra Seoighe nó "Maoilrín" mar a thugtaí le cion air sa cheantar, "John Joyce" as Béarla. Ceaptar ná raibh aon fhocal den Bhéarla in aon chor aige. Deir Waldron "he may as well have been in China, for not one solitary word of the English did he understand ${ }^{60}$ ". Ní raibh fear teanga ann an chuid is mó den am dó, ní raibh cead cainte aige. Tá an diúltú don tiontú chomh tábhachtach céanna leis an dtiontú féin. An choir a cuireadh ina leith ach gur bhatráil sé Máiréad Seoighe, col ceathrair leis féin agus gan na déaga féin slánaithe aici. Sa chuntas ar an Seoigheach tarraingíodh na piseoga anuas arís. Luadh nach mbainfeadh duine le corpán an té a mharaigh sé féin ach thrasnaigh an Aturnae Ginearálta é agus olc an duine shibhialta air, "tell that to distant ages, old gossips and so forth, but don't tell it to us who know the history of criminals and crime ${ }^{61}$ ". Tugtar le fios go mbíonn stair ag Béarlóirí agus seanchaint ag Gaeilgeoirí. Thiar i nDúiche Sheoigheach bhí tuairiscí ón Freeman's Journal á n-aistriú thar n-ais go Gaeilge. Is fianaise é seo dar ndóigh go raibh léitheoireacht ag cuid de na daoine ar a laghad ag an am. Chuardaigh an Chúirt cáilíochtaí sibhialta d'aon ghnó. Mhol an breitheamh Máire Seoighe, "that intelligent girl who spoke English ${ }^{62}$ ". Bhí suim faoi leith i meabhair chinn an dúchasaigh, "'intelligence' was the mark of advanced races, at home or abroad; it distinguished them from 'savages'63". Síleadh go minic go raibh meabhair chinn an duine de réir an chine nó na haicme.

Maraíodh Bríd Ní Chléire sa bhliain 1895 i gCluain Meala, trí bliana déag ó crochadh Maolra Seoighe. Ní raibh aon leisce ar an bpaiteolaí tagairt do na Hottentots sa chás áirithe sin, deir Bourke "Coroner Shee's remark was to be the first in a long series of analogies drawn - or repudiated - between the Irish people and various African civilizations in the weeks that followed ${ }^{64 "}$. D'oibrigh na nuachtánaithe leis na trópanna luatha seandálaíocha, eitneagrafaíocha nó antraipeolaíochta a rinne amach gur cultúr neamhshibhialta, réamhnua-aoiseach nó primitíveach a bhí sa chultúr dúchais. Cultúr a bhí chun deiridh ar chultúr an Bhéarla mar shampla. Nuair a tugadh na príosúnaigh amach ar sráideanna Chluain Meala, "much of the hissing and groaning was directed at Denis Ganey. His traditional title, 'fairy doctor' - uncomfortably close to 'witch-doctor' - was enough to single him out for opprobrium, in the modern town of Clonmel ${ }^{65 "}$ ". Chuadar i muinín "the language of social Darwinism"6", "'savages', with high cheekbones, protruding jaws and low morals were to be found not only in Africa, or even in Ireland, but in the white urban underclass of Britain itself ${ }^{67}$.

Ardán a bhí sa chúirt ar a cuireadh, mar a ceapadh, eiseamláir den primitíveach. D'imigh an giúiré amach ach chasadar ar na sála geall leis, ní raibh ach sé nóiméid caite amuigh acu. Nuair a d'aistrigh an fear teanga breith na cúirte do Mhaolra Seoighe baineadh siar as go mór de réir an fhianaise a mhaireann. Tháinig leathadh ladhar air agus chrom sé ar ghuíodóireacht agus ar gholchás. Scríobh iriseoir mar gheall ar "the sonorous sounds of the mountain Gaelic in which he apostrophised ${ }^{68 "}$. Tá sé sáinnithe i ngreim docht na teanga móire faoi fhallaí arda tuisceana. Níl ina ghearán géar déanach féin ach mar a bheadh gliogar srutháin, is amhlaidh a chuireann an glór rómánsúil Ceilteach ó bhruach na sibhialtachta leis an dtaispeántas, "that apparently primitive and remote part of the country ${ }^{69}$ ". Is léir go raibh tuiscintí comhaimseartha ar shibhialtacht agus ar chultúr na tíre á bplé sa chúirt. Labhair Tim Harrington, feisire Parlaiminte: 
It may be well for persons of noble sentiment and high mental culture to state that they would face a murderer's death rather than admit a murder they never committed, but these men are ignorant, poverty-stricken, wretched peasants ${ }^{70}$.

Is ábhar suime go raibh an nuachtán náisiúnaíoch The Freeman's Journal ar aon fhocal leis an mbreitheamh agus le hiriseoireacht na Breataine. Is faide a chuaigh an iris áfach, chuaigh sí ar chiníochas agus chuir an eachtra i gcomparáid le "traditions of coppercoloured savagery ${ }^{71}$ ". Nuair a loirg abhcóide cosanta trua dóibh ó John Poyntz, Earl Spencer, dúirt sé nár thuigeadar an ceart mar gheall ar "their ignorance of our language, our social civilisation and our laws ${ }^{72}$. Is rómhaith a thuigeadar an teanga, an tsibhialtacht agus an dlí sin faoi dheireadh na trialach. Thrácht Spencer leis ar "the ignorant people of the west" mhol sé go gcrochfaí duine amháin ná raibh ciontach ar a laghad díreach chun "ceacht a mhúineadh" dóibh ${ }^{73}$ (138).

Áitíonn Barthes mar gheall ar affaire Dominici go mbuaileann La Figaro le aoire na ngabhar. I gcás Mhaolra Seoighe buaileann The Irish Hudibras le haoire na gcaorach: casann an tsamhlaíocht liteartha léannta leis an réalaíocht eitneagrafaíoch. I gcás Dominici ní ó theanga go teanga a bhíothas ag tiontú fiú ach ó chanúint go canúint ach fós ní ligfeadh fairsinge an domhain eatarthu dóibh teacht ar aon aigne, "syntax, vocabulary, most of the elementary analytical materials of language grope blindly without ever touching ${ }^{74 " . ~ A r ~}$ chúl na mbreitheamh bhí na húdair, in áit na habhcóide an scéalaí iontach, tagann na póilíní féin isteach ar seánra na tuarascála agus na húrscéalaíochta:

\begin{abstract}
Justice took the mask of Realist literature, of the country tale, while literature itself came to the court-room to gather new "human" documents, and naively to seek from the face of the accused and the suspects the reflection of a psychology which, however, it had been the first to impose on them by the arm of the $\operatorname{law}^{75}$.
\end{abstract}

Bhí na cúisithe, Seoighe agus Dominici, in amharclann na cúirte fad is a cuireadh seánraí liteartha léannta na linne trí chéile. Carachtair ab ea iad geall leis, dramatis personae, pearsna a bhí á gcumadh i ganfhios dóibh féin ar stáitse sleamhain an chultúir ghradamaigh. B'iad na príomhphearsna, eiseamail chríochnaithe den tuathánach tipiciúil, malairt an tsaoránaigh nua-aoisigh shibhialta, "being judged by a power which wants to hear only the language it lends us ${ }^{76 "}$.

\title{
Conclúid
}

I gcúrsaí léann na hÉireann bíonn sé le tuiscint go minic gur aon teanga amháin a bhíonn i gceist "dáiríre". Níor mhiste teoiric an aistriúcháin a mheabhrú mar chuid de dheachleachtas scolártha. Tá sé de bhua aici go gcuireann sé dhá theanga san áireamh ar a laghad. Ní díreach díluchtú ó chultúr amháin go dtí cultúr eile é, bunthróp i léann na tíre trí chéile. Cuireann sé ann don intinn: tugann sé mapa an róid don taighdeoir, líníocht mhín a nochtann taibhse an chultúir. Coinníonn sé an chumarsáide agus an fhiosracht ar siúl. Is gnách leis an dteanga sprioctha, go háirithe an Béarla, an teanga bhunaidh a chur de ar fad agus an nasc a bhriseadh. Tá sé ráite go minic gur téadán an tiontú a thugann isteach i gcathair ghríobháin na brí tú ach tugann sé ar ais chomh maith tú. Idir dhá 
cheann an aistriúcháin, an teanga bhunúil agus an teanga sprioctha, tá samhlaíocht, hidbrideacht agus cruthaitheacht.

An gá is mó a bhíonn le haistriúcháin ó Ghaeilge ná éileamh mór i saol an Bhéarla do eolas ar an dtír a shásamh. Déantar uirlis den léann nó den teanga i gcásanna áirithe chun an teolas seo a chur ar fáil i dteangacha agus i gcomhtheascaí eile; comhthéacs Ceilteach nó Éireannach mar shampla. Chítear an téarma Irish Studies i dtosach an fichiú haois i gcéaduair "denoting the philology of the Irish language, what we would today call 'Celtic Studies"'77. Tuigeann gach mac léinn go mbíonn béim as cuimse ar ghramadach agus ar fhocleolaíocht. Ní ó fhocal go focal a bhíonn téacs (dán, amhrán, scéal, cultúr, gníomh nó saorgán fiú) á thiontú ach ó thuiscint go tuiscint. Ní bheadh aon fháil ag an dteanga sprioctha ar an dtéacs in éagmais an aistriúcháin. Teipeann ar aistriúcháin uaireanta. Ní bhíonn aon chur amach an-mhinic ar an leagan bunúil, níl ann ach an t-aistriúchán. Rud eile, ní gach aon téacs a bhíonn i gceist ach rogha áirithe a mbíonn cúiseanna faoi leith leis (marú, piseog, nós); míreanna slána oiriúnacha a chomhlíonann critéir réamhcheaptha sa chultúr. Bíonn baint ag polaitíocht, ag eacnamaíocht, ag inscne, ag aicme, ag stair, ag creideamh leis an rogha. In éagmais na teanga bunúla ní bhíonn fhios ag tomhaltóir an aistriúcháin (téacs nua, íomhá, tuiscint, cultúr, traidisiún) i gcónaí an leagan muiníneach é in aon chor. Is cuma uaireanta, uaireanta eile ní thuigtear go gcrochfadh tiontú duine is bhfágfadh ina dhiaidh an leagan de a chum agus a cheap sé féin. Asfalt an charrchlóis a cuireadh anuas ar Mhaolra Seoighe ar láthair an tseanphríosúin mar atá Ard-Eaglais chathair na Gaillimhe. Clocha garbha i reilig Chnoc an Teampaill atá ar an líon tí a maraíodh.

\section{NOTES}

1. Kim Lenaghan, Irish Superstitions and Lore, Baile Átha Cliath, Appletree Press, 2009, p. 7.

2. Joesph Ivimey, History of the English Baptists: Vol. IV, 1830, Londain, Isaac Taylor Hinton, p. 171.

3. James Joyce (aistriúcháin de chuid Conor Deane) i Kevin Barry (eag.), James Joyce Occasional Critical and Political Writing, Oxford, Oxford World Classics, 2000, 1. 145-7.

4. André Lefevere, Translation/History/Culture: A Sourcebook, Londain, Routledge, l. XI.

5. Lawrence Venuti, The Translator's Invisibility: a History of Translation, Londain, Routledge, 1995, 1. 17.

6. Omar S. Al-Shabab, Interpretation and the Language of Translation, Londain, Janus, 1996, 1. 8.

7. Brian Friel, Translations, Londain, Faber, 1981, 1. 32.

8. André Lefevere, op. cit., 1. 2.

9. David Spurr, The Rhetoric of Empire: Colonial Discourse in Journalism, Travel Writing and Imperial Administration, Londain, 1993, 1. 4. 
10. Anuradha Dingwaney and Carol Maier (eds), Between Languages and Cultures: Translation and Cross-cultural Texts, Pittsburgh, 1995, 1. 4.

11. Lawrence Venuti, The Translator's Invisibility: A History of Translation, op.cit, , 1. 5.

12. Román Álvarez and Carmen-África Vidal (eds), "Translating: a political act”, in Román Álvarez and Carmen-África Vidal (eds), Translation, Power, Subversion, Clevedon, 1996, 1. 1.

13. Ovidio Carbonell, "The exotic space of cultural translation", in Román Álvarez and Carmen-África Vidal (eds), op. cit.

14. Richard Jacquemond, "Translation and cultural hegemony: the case of French-Arabic translation" in Lawrence Venuti (eag), Rethinking Translation: Discourse, Subjectivity, Ideology, 1. 148.

15. M. Tymoczko, "Translation and Meaning", in F. Guenthner and M. Guenthner-Reutter (eds), Meaning and Translation: Philosophical and Linguistic Approaches, New York, NYU Press, 1978, 1. 29.

16. Gisli Pálsson, Introduction. In G. Pálsson (ed.), Beyond boundaries: Understanding, Translation and Anthropological discourse, Oxford, Berg, 1993, 1. 1.

17. Michael Cronin, Translating Ireland, Cork, Cork University Press, 1996, 1. 92.

18. Stiofán Ó Cadhla, Cá bhfuil Éire? Guth an Ghaisce i bprós Sheáin Uí Ríordáin, Baile Átha Cliath, An Clóchomhar, 1998, 1. 41.

19. Stiofán Ó Cadhla, Civilising Ireland: Ordnance Survey 1824-1842: Ethnography, Cartography, Translation. Baile Átha Cliath, Irish Academic Press, 2007, 1.228.

20. Gisli Pálsson, op. cit., l. 16.

21. Michael Cronin, op. cit., 1. 92.

22. Ian J. McNiven agus Lynette Russell, Appropriated Pasts: Indigenous Peoples and the Colonial Culture of Archaeology, Lanham, AltaMira Press, 2005, 1. 8.

23. Michael Cronin, op. cit., 1. 105.

24. Ibid., 1. 107.

25. Robin Flower, The Western Island, Oxford, Clarendon Press, 1944, 1. 6.

26. Lawrence Venuti, "Translation as cultural politics: regimes of domestication in English", in Textual Practice 7:2, 1993, 1. 209.

27. Ibid.

28. David Spurr, The Rhetoric of Empire: Colonial Discourse in Journalism, Travel Writing and Imperial Administration, Londain, Duke University Press, 1993, 1. 28.

29. Roland Barthes, Mythologies, Nua-Eabhrac, Noonday Press, 1972, 1. 43.

30. David Brett, The Construction of Heritage, Corcaigh, Cló Ollscoile Chorcaí, 1996, 1. 38.

31. Ibid.

32. Stiofán Ó Cadhla, Civilising Ireland: Ordnance Survey 1824-1842: Ethnography, Cartography, Translation, op. cit., 1. 17.

33. John P. Harrington, The English Traveller in Ireland: Accounts of Ireland and the Irish Through Five Centuries, Baile Átha Cliath, Wolfhound Press, 1991, l.199.

34. Ibid., 1.211.

35. Ibid., 1.228 .

36. Ibid., 1.243. 
37. Ibid., 1.255 .

38. Ibid.

39. David Brett, op. cit., 1. 45.

40. E.M. Forster, “Introduction”, in Maurice O’Sullivan, Twenty Years a Growing, New York, Oxford University Press, 1933, 1. 9.

41. Roland Barthes, op. cit., 43.

42. Mc Niven agus Russell, op. cit., 1. 51.

43. Ibid., 1. 61.

44. Ibid., 1. 63.

45. Ibid., 1. 76.

46. William Wilde, Irish Popular Superstitions, Baile Átha Cliath, Cló Acadúil na hÉireann, 1979 (1852) 1. 11.

47. Estyn Evans, Irish Folk Ways. Londain, Routledge and Kegan Paul, 1957, 1. 3.

48. Brian Ó Conchubhair, Fin de Siécle na Gaeilge: Darwin, an Athbheochan agus Smaointeoireacht na hEorpa, 2009, Indreabhán, Cló Iar-Chonnachta, 1. 4.

49. Bell agus Watson, 1. 41.

50. Jarleth Waldron, Maamtrasna: The Murders and the Mystery, Baile Átha Cliath, Edmund Burke Publisher, 1992, 1. 19.

51. Ibid., 1. 25.

52. Ibid., 1. 27.

53. Ibid., 1. 31.

54. Ibid., 1. 54.

55. Ibid., 1. 60.

56. Ibid., 1. 83.

57. Ibid., 1. 103.

58. Roland Barthes, op. cit., 1.44.

59. Jarlath Waldron, op. cit., 1. 106.

60. Ibid., 1. 108.

61. Ibid., 1. 118.

62. Ibid., 1. 120.

63. Angela Bourke, The Burning of Bridget Cleary: A True Story, Londain, Pimlico, 1999, 1. 122.

64. Ibid., 1. 115.

65. Ibid., 1. 119.

66. Ibid., 1. 121.

67. Ibid.

68. Ibid., 1. 122.

69. Ibid., 1. 123.

70. Ibid., 1. 129.

71. Ibid., 1. 132.

72. Ibid., 1. 133. 
73. Ibid., 1. 138.

74. Roland Barthes, op. cit., 1. 44.

75. Ibid., 1. 66.

76. Ibid.

77. James McKillop, “Omnia Hibernica: How ACIS Brought Irish Studies to the Academy”, in Irish Literary Supplement 11. 2010,22, Uimh. 2.1., 1. 24.

\section{RÉSUMÉS}

Cet article étudie la traduction à travers le prisme de l'ethnographie, afin de mesurer l'apport culturel dans l'acte traductologique. Sur le plan culturel, le transfert se fait non pas d'une langue à une autre mais d'un peuple à un autre, voire d'un idiome à un autre. Cet article tente de démontrer l'importance de la traduction dans l'ethnographie, dans le folklore et dans les études irlandaises à travers l'exemple des meurtres de Mam Trasna, puis établit une brève comparaison avec l'affaire Dominici.

San alt seo pléitear tionchar an aistriúcháin ar an dtuiscint a bhaintear as an gcultúir nó ar an léamh a dhéantar ar an gcultúr ar bhonn eitneagrafaíochtúil. Ar leibhéal an chultúir ní ó theanga go teanga a thiontaítear i gcónaí ach ó thuiscint go tuisicint, ó phobal go pobal nó ó seanrá go seanrá. Maítear gur cuid de dheachleachtas tábhachtach léannta ó thaobh na heitneagrafaíochta, an bhéaloidis nó léann na hÉireann an t-aistriúchán a chur san áireamh. Déantar staidéar faoi leith ar chás Mhaolra Seoighe agus cruthaítear ceagail idir an cás sin agus an affaire Dominici sa bhFrainc.

\section{INDEX}

Keywords : ethnography, folklore, translation, Franco-Irish relations, languages in Ireland gaelic

Mots-clés : ethnographie, relations franco-irlandaises, folklore, langues en Irlande - gaélique, traduction

\section{AUTEUR}

\section{STIOFÁN Ó CADHLA}

Coláiste na hollcoile, Corcaigh 